\title{
INNOVATION AS A FACTOR OF SOCIO-ECONOMIC DEVELOPMENT OF MUNICIPAL EDUCATION (FOR EXAMPLE, THE REPUBLIC OF TATARSTAN)
}

\author{
A INOVAÇÃO COMO FATOR DE DESENVOLVIMENTO SOCIOECONÔMICO DAS \\ EDUCAÇÕES MUNICIPAIS (POR EXEMPLO, A REPÚBLICA DO TARTARISTÃO)
}

LA INNOVACIÓN COMO FACTOR DE DESARROLLO SOCIOECONÓMICO DE LAS EDUCACIONES MUNICIPALES (POR EJEMPLO, LA REPÚBLICA DE TATARSTÁN)

\author{
Aida I. LAZARCHIK ${ }^{1}$ \\ Elnara E. ZAINUTDINOVA ${ }^{2}$ \\ Irina A. AHMETOVA ${ }^{3}$
}

\begin{abstract}
The article reveals conceptual dispositions of socioeconomic development, explores the problems of the current stage of implementation of the concept of socioeconomic development in the municipalities. Standards of financial improvement in the regions, led by the Ministry of Economy of the Republic of Tatarstan, are contemplated. The markers of the financial progress of the districts are thought out. The milestones of financial advancement are distinguished and defended. Several important developments for the use of financial improvement in the regions are envisioned. In accordance with the guidelines of the fundamental documents adopted in the aspect of socioeconomic development, criteria and indicators were identified to assess the economic, social and environmental situation at various levels of the social system. In the light of the investigation of the methodological advances of the Ministry of Economy of the Republic of Tatarstan, the measures and markers are analyzed in order to allow us to research the degree of financial improvement of the structure. According to data from Tatarstan, the volume of shipments of innovative products, labor, services (millions of rubles) from the municipal districts and urban districts of the Republic of Tatarstan for 2015-2018 is summarized and analyzed. Suggestions are made to improve methodological approaches to analysis and evaluation of the system's socioeconomic development level in its various aspects.
\end{abstract}

KEYWORDS: Socio-economic development. Municipalities. Innovations. Problems and contradictions.

RESUMO: O artigo revela disposições conceituais de desenvolvimento socioeconômico, explora os problemas do atual estágio de implementação do conceito de desenvolvimento socioeconômico nos municípios. Os padrões de melhoria financeira das regiões, liderados

1 Kazan Federal University (KPFU), Kazan - Russia. Senior Lecturer of the Department of Production Economics. Institute of Economics and Finance. ORCID: https://orcid.org/0000-0001-5684-1739. E-mail: laidaigorevna@mail.ru

${ }^{2}$ Kazan Federal University (KPFU), Kazan - Russia. Associate Professor of the Department of Production Economics. Institute of Economics and Finance. ORCID: https://orcid.org/0000-0002-3424-9862. E-mail: elnazaj@mail.ru

${ }^{3}$ Kazan Federal University (KPFU), Kazan - Russia. Associate Professor of the Department of Production Economics, Institute of Economics and Finance. ORCID: https://orcid.org/0000-0003-0996-7712. Email:iraahmetova@mail.ru

RPGE- Revista on line de Política e Gestão Educacional, Araraquara, v. 25, n. esp. 1, p. 472-481, mar. $2021 . \quad$ e-ISSN:1519-9029 DOI: https://doi.org/10.22633/rpge.v25iesp.1.14984 
pelo Ministério da Economia da República do Tartaristão, são contemplados. Os marcadores do avanço financeiro dos distritos são pensados. Os marcos do avanço financeiro são distinguidos e defendidos. Vários empreendimentos importantes para o uso da melhoria financeira das regiões são imaginados. De acordo com as diretrizes dos documentos fundamentais adotados no aspecto do desenvolvimento socioeconômico, foram identificados critérios e indicadores para avaliar a situação econômica, social e ambiental em vários níveis do sistema social. À luz da investigação dos avanços metodológicos do Ministério da Economia da República do Tartaristão, as medidas e os marcadores são analisados de forma a nos permitir pesquisar o grau de melhoria financeira da estrutura. De acordo com os dados do Tartaristão, o volume de remessas de produtos inovadores, trabalho, serviços (milhões de rublos) dos distritos municipais e distritos urbanos da República do Tartaristão para 20152018 é resumido e analisado. São formuladas sugestões para melhorar as abordagens metodológicas de análise e avaliação do nível de desenvolvimento socioeconômico do sistema em seus diversos aspectos.

PALAVRAS-CHAVE: Desenvolvimento socioeconômico. Municípios. Inovações. Problemas e contradições.

RESUMEN: El artículo revela disposiciones conceptuales del desarrollo socio-económico, explora la etapa actual de los problemas de implementación del concepto de desarrollo socio-económico de los municipios. Se contemplan los patrones de mejora financiera de las regiones liderados por el Ministerio de Economía de la República de Tartaristán. Se piensa en los marcadores del progreso financiero de los distritos. Se distinguen y defienden las diligencias del avance financiero. Se calculan diversas iniciativas importantes para el aprovechamiento de la mejora financiera de las regiones. De acuerdo con los lineamientos de los documentos fundamentales adoptados en el aspecto de la formación e implementación de disposiciones conceptuales de desarrollo socioeconómico, se han identificado criterios e indicadores para evaluar la situación económica, social y ambiental en los distintos niveles del sistema social. A la luz de la investigación de los avances metodológicos del Ministerio de Economía de la República de Tartaristán, se consideran medidas y marcadores que nos permiten evaluar el grado de mejora financiera del marco. Según los datos de Tatarstan, el volumen de bienes, trabajos y servicios innovadores enviados (millones de rublos) de los distritos municipales y distritos urbanos de la República de Tatarstán para 2015-2018 se resume y analiza. Se formulan sugerencias para mejorar los enfoques metodológicos del análisis y evaluación del nivel de desarrollo socioeconómico del sistema en sus diversos aspectos.

PALABRAS CLAVE: Desarrollo socioeconómico. Municipios. Innovaciones. Problemas y contradicciones.

\section{Introduction}

Municipalities, being the essential connection in the structure of the Russian Federation, make an immense commitment to the financial improvement of the nation. The President of the Russian Federation in his Address to the Federal Assembly in 2020 noticed, that public activities are worked for the person to guarantee a high caliber of life for the 
population. The results of project implementation should be noticeable in each subject of the Russian Federation and in each municipality ${ }^{4}$.

The financial advancement of regions is a need in the improvement of the monetary strategy of the Russian Federation.

The socio-economic development of municipalities is influenced by such factors as: the municipality economic development, the demographic situation, the natural resources base of the municipalities, the municipalities' investment attractiveness, the territory infrastructure, the tourist attractiveness, the municipality competitiveness, the small business development, the innovative development of the municipal economy.

\section{Methods}

The material for the work was the data on the rating of socio-economic development of municipal districts and urban districts of the Republic of Tatarstan for 2015-2018, conducted annually by the Ministry of Economy of the Republic of Tatarstan, as well as statistics on the Republic of Tatarstan.

\section{Results and discussions}

The tasks identified by the President of the Russian Federation for implementation in the near future echoes the concept of sustainable development, first voiced at the United Nations International Commission in 1987, in the report "Our Common Future". The idea of feasible advancement likewise alludes to measures pointed toward saving the soundness of the populace, ensuring the earth, dispensing with neediness, taking care of the segment issue, admittance to instruction, and improving the personal satisfaction of society.

The association of districts of the Republic of Tatarstan is done as per the Federal Law of October 6, 2003 No. 131-FZ "On General Principles of the Local Self-Government Organization in the Russian Federation".

The Republic of Tatarstan includes 956 municipalities: 43 municipal districts, 2 urban districts, 39 urban settlements, 872 rural settlements.

The Republic of Tatarstan is a subject of the Russian Federation and is remembered for the Volga Federal District. The number of inhabitants in the Republic as of January 1, 2019 is 3898,6 thousand individuals ${ }^{5}$.

${ }^{4}$ Available: http://kremlin.ru/. Access: 10 dec. 2020.

RPGE- Revista on line de Política e Gestão Educacional, Araraquara, v. 25, n. esp. 1, p. 472-481, mar. $2021 . \quad$ e-ISSN:1519-9029 DOI: https://doi.org/10.22633/rpge.v25iesp.1.14984 
The socio-economic development of municipalities is influenced by such factors as: the municipality economic development, the demographic situation, the natural resources base of the municipalities, the municipalities' investment attractiveness, the territory infrastructure, the tourist attractiveness, the municipality competitiveness, the small business development, the innovative development of the municipal economy.

It is impossible to consider the socio-economic development of municipalities given the innovative component. To develop an economy with a high technological level, it is necessary to assess the innovative potential of municipalities, build a system of innovative development of the municipality and form its competitive advantages. It is important that in nations with created economies the making of a viable development framework is one of the primary bearings of government strategy. Also, monopolies on high-tech links in the value chain are included in the priority areas (LAZARCHIK, 2020, p. 106).

According to Y. Korea innovation affects all factors of competitive advantage. Innovative developments contribute to increased competition between firms and enterprises, affect the sectoral structure of the economy (KOREA, 1993, p. 105).

It is worth noting that in modern economic conditions, most regions and municipalities show a tendency to reduce the pace of socio-economic development. Of course, this is due to the lack of financial investments for technological re-equipment of production, depreciation of equipment, outdated technologies at industrial enterprises, as well as housing and communal services. And as a result, the volume of speculations diminishes, nearby governments can't give the populace an elevated expectation of living, the region is losing its upper hands (LAZARCHIK, 2020, p. 106).

The meaning of innovative development is to change the nature of the socio-economic development of the municipality.

To decide the degree of regions' financial improvement of the Republic of Tatarstan, the Ministry of Economy of the Republic of Tatarstan conducts a rating of financial advancement of city areas and metropolitan regions of the Republic of Tatarstan.

Table 1 presents the rating of socio-economic development of the municipal districts and urban districts of the Republic of Tatarstan for 2015-2019. 
Table 1 - Rating of socio-economic development of municipal districts and urban districts of the Republic of Tatarstan for 2015-2018

\begin{tabular}{|c|c|c|c|c|}
\hline \multirow[t]{2}{*}{ Name of the municipal district (urban district) } & \multicolumn{4}{|c|}{ Total rating } \\
\hline & 2015 & 2016 & 2017 & 2018 \\
\hline \multicolumn{5}{|c|}{ Municipal districts with a center - a city of republican subordination and urban districts } \\
\hline Kazan & 1 & 1 & 1 & 1 \\
\hline Almetjevsk & 2 & 2 & 2 & 2 \\
\hline Nizhnekamsk & 3 & 3 & 3 & 3 \\
\hline Leninogorsk & 4 & 4 & 8 & 7 \\
\hline Aznakaevo & 5 & 5 & 7 & 8 \\
\hline Nurlat & 6 & 6 & 5 & 5 \\
\hline Naberezhnye Chelny & 7 & 7 & 4 & 4 \\
\hline Elabuga & 8 & 8 & 6 & 6 \\
\hline Bugulma & 9 & 9 & 9 & 10 \\
\hline Zainsk & 10 & 10 & 11 & 9 \\
\hline Zelenodolsk & 11 & 11 & 10 & 11 \\
\hline Bavly & 12 & 12 & 13 & 12 \\
\hline Buinsk & 13 & 13 & 12 & 13 \\
\hline Chistopol & 14 & 14 & 14 & 14 \\
\hline \multicolumn{5}{|l|}{ Municipal areas with urban and rural populations } \\
\hline Laishevo & 1 & 1 & 1 & 1 \\
\hline Mendeleevo & 2 & 2 & 3 & 3 \\
\hline Sarmanovo & 3 & 3 & 2 & 2 \\
\hline Apastovo & 4 & 4 & 8 & 13 \\
\hline Yutazinsk & 5 & 5 & 10 & 11 \\
\hline Agryz & 6 & 6 & 11 & 16 \\
\hline Menzelinsk & 7 & 7 & 17 & 10 \\
\hline Sabinskiy & 8 & 8 & 6 & 7 \\
\hline Aksubaevo & 9 & 9 & 4 & 4 \\
\hline Mamadysh & 10 & 10 & 5 & 6 \\
\hline Kamsko-Ustinskiy & 11 & 11 & 15 & 18 \\
\hline Arsk & 12 & 12 & 14 & 15 \\
\hline Baltasi & 13 & 13 & 16 & 17 \\
\hline Kukmor & 14 & 14 & 12 & 14 \\
\hline Alekseevsk & 15 & 15 & 7 & 5 \\
\hline Tetyushskiy & 16 & 16 & 9 & 9 \\
\hline Rybno-Slobodskiy & 17 & 17 & 13 & 12 \\
\hline Spass & 18 & 18 & 18 & 8 \\
\hline
\end{tabular}

RPGE- Revista on line de Política e Gestão Educacional, Araraquara, v. 25, n. esp. 1, p. 472-481, mar. $2021 . \quad$ e-ISSN:1519-9029 DOI: https://doi.org/10.22633/rpge.v25iesp.1.14984 


\begin{tabular}{|l|l|l|l|l|}
\hline Tukaevskiy & 1 & 1 & 1 & 1 \\
\hline Verkhneuslonskiy & 2 & 2 & 3 & 2 \\
\hline Novosheshminskiy & 3 & 3 & 2 & 3 \\
\hline Pestrechinskiy & 4 & 4 & 4 & 4 \\
\hline Cheremshanskiy & 5 & 5 & 6 & 5 \\
\hline Aktanyshs & 6 & 6 & 5 & 6 \\
\hline Vysokogorskiy & 7 & 7 & 7 & 7 \\
\hline Tyulyachinskiy & 8 & 8 & 12 & 12 \\
\hline Drozhzhanovskiy & 9 & 9 & 10 & 10 \\
\hline Alkeevskiy & 10 & 10 & 9 & 8 \\
\hline Kajbitskiy & 11 & 11 & 13 & 13 \\
\hline Atninskiy & 12 & 12 & 11 & 9 \\
\hline Muslumovo & 13 & 13 & 8 & 11 \\
\hline
\end{tabular}

Source: Prepared by the authors

Table 2 shows the volume of dispatched imaginative products, works, and administrations of regions and metropolitan areas of the Republic of Tatarstan for 2015-2018, in million rubles.

Table 2 - Volume of shipped innovative goods, works, and services of municipalities and urban districts of the Republic of Tatarstan for 2015-2018, in million rubles

\begin{tabular}{|l|l|l|l|l|l|}
\hline \multirow{2}{*}{ Name of the municipal district (urban district) } & \multicolumn{4}{l}{ Volume of shipped innovative goods, works, services } \\
\cline { 2 - 5 } & 2015 & 2016 & 2017 & 2018 \\
\hline Municipal districts with a center - a city of republican subordination and urban districts \\
\hline Kazan & 62165,4 & 71509,9 & 62166,1 & 55524,4 \\
\hline Almetjevsk & 186215,7 & 199583,1 & 246502,7 & 342489,0 \\
\hline Nizhnekamsk & 89596,6 & 66552,5 & 71482,2 & 109314,9 \\
\hline Leninogorsk & - & - & - & 15,1 \\
\hline Aznakaevo & 294,6 & 36,2 & 69,1 & 64,3 \\
\hline Nurlat & - & - & - & - \\
\hline Naberezhnye Chelny & 15561,7 & 30067,8 & 28293,6 & 56921,9 \\
\hline Elabuga & 3624,6 & 3304,6 & 3608,2 & 3664,1 \\
\hline Bugulma & 280,7 & 381,5 & 234,1 & 405,2 \\
\hline Zainsk & - & 189,9 & 278,7 & - \\
\hline Zelenodolsk & 4788,0 & 5635,3 & 8375,6 & 4618,7 \\
\hline Bavly & 13,4 & 45,0 & 23,3 & - \\
\hline Buinsk & 17,0 & - & - & - \\
\hline Chistopol & 1719,6 & 1120,8 & 147,7 & 139,5 \\
\hline
\end{tabular}




\begin{tabular}{|c|c|c|c|c|}
\hline \multicolumn{5}{|c|}{ Municipal areas with urban and rural populations } \\
\hline Laishevskiy & 852,8 & 867,1 & 1383,1 & 2785,0 \\
\hline Mendeleev & 4921,9 & 10876,8 & 12337,9 & 8806,8 \\
\hline Sarmanovo & - & - & - & - \\
\hline Apastovo & - & - & - & - \\
\hline Yutazinsk & 6,4 & 34,9 & 78,3 & 33,8 \\
\hline Agryz & - & - & - & - \\
\hline Menzelinsk & 25,6 & 21,2 & 17,6 & 18,9 \\
\hline Sabinskiy & - & - & - & - \\
\hline Aksubaevo & - & - & - & - \\
\hline Mamadysh & - & - & - & - \\
\hline Kamsko-Ustinskiy & - & - & - & - \\
\hline Arsk & - & - & - & - \\
\hline Baltasi & - & - & - & - \\
\hline Kukmor & - & - & - & - \\
\hline Alekseevsk & - & - & 0,3 & \\
\hline Tetyushskiy & - & - & - & - \\
\hline Rybno-Slobodskiy & - & - & - & - \\
\hline Spass & - & - & - & - \\
\hline \multicolumn{5}{|c|}{ Municipal areas with only rural population } \\
\hline Tukaevskiy & 2262,8 & & 397,9 & 402,0 \\
\hline Verkhneuslonskiy & - & 5,7 & 31,0 & 346,2 \\
\hline Novosheshminskiy & - & - & - & - \\
\hline Pestrechinskiy & - & - & - & - \\
\hline Cheremshanskiy & - & - & - & - \\
\hline Aktanyshs & - & - & - & - \\
\hline Vysokogorskiy & 824,3 & 916,2 & 130,6 & 1115,9 \\
\hline Tyulyachinskiy & - & - & - & - \\
\hline Drozhzhanovskiy & - & - & - & - \\
\hline Alkeevskiy & - & - & - & - \\
\hline Kajbitskiy & - & - & - & - \\
\hline Atninskiy & - & - & - & - \\
\hline Muslumovo & - & - & - & - \\
\hline
\end{tabular}

Source: Prepared by the authors 
So, in terms of the volume of shipped innovative goods, works, services from 20152018, the most attractive among municipal districts with a center - a city of republican subordination and urban districts are Almetjevsk, Nizhnekamsk districts, Kazan and Naberezhnye Chelny. The least attractive are the Buninsk and Chistopol districts.

Among the municipal districts with urban and rural populations, the most attractive are the Mendeleev and Laishevskiy districts. The least attractive are Spass, Rybno-Slobodskiy, Tetyushskiy, Kukmor, Baltasi, Arsk, Kamsko-Ustinskiy, Mamadysh, Aksubaevo, Sabinskiy districts.

Among the municipalities having only the rural population, the most attractive are Tukaevskiy, Vysokogorskiy and Verkhneuslonskiy districts. The least attractive are Muslumovo, Atninskiy, Kaybitskiy, Alekseevskiy, Drozhzhanovskiy, Tyulyachinskiy, Aktanysh, Cheremshanskiy, Pestrechinskiy and Novosheshminskiy districts. It should be noted, that between the municipalities there is a significant difference in the volume of shipped innovative goods, works and services.

So, looking at the volume of delivered inventive merchandise, works, administrations of districts and their place in the positioning of financial advancement of regions for 20152018, we see that there is a connection between the volume of dispatched creative products, works and benefits and their rating in financial turn of events. Those regions, where the marker mirroring the volume of sent creative merchandise, work, administrations is high, involve the primary spots in the positioning.

\section{Conclusion}

In our opinion, the innovative activity of organizations shows the specifics of the socio-economic development of municipalities.

The term "innovation" is interpreted in regional and federal legal acts related to changes in the economic sphere. It is worth noting that from the perspective of the municipalities' development, innovations only in the economy do not fully reveal the specifics of the changes. From the point of view of the municipalities' development, it is not enough to evaluate innovation only as an improved or new product or technological process (ILYENKOVA et al., 1997, p. 9). Without a doubt, from the perspective of the regions' turn of events, advancements are changes in both open existence of the populace and natural insurance, executed as parametric attributes. Also, simultaneously, advancements during the time spent financial improvement are the consequence of creative exercises pointed toward 
presenting another item or mechanical cycle, creating and actualizing new projects for the improvement of the neighborhood network, and likewise, extra undertakings that follow.

Advancement, presented in the financial arrangement of any level, is consistently the consequence of scholarly work pointed toward getting another item, another innovation and another program for the improvement of society. From the perspective of the regions' turn of events, such elements of development as: organizational, social, transformative, environmental are especially important. It is worth noting that organizational innovations provide an opportunity to save material resources, labor costs, which is most valuable for business relationships in municipalities.

The economy of municipalities is faced with issues of introducing innovations related to the lack of readiness of institutions, lack of local community understanding, and lack of resources. The solution of emerging issues is possible with the help of methods of managing the socio-economic development of the municipality, which go beyond the scope of interested parties, by informing the local population and involving authorities.

ACKNOWLEDGEMENTS: The work is performed according to the Russian Government Program of Competitive Growth of Kazan Federal University.

\section{REFERENCES}

ILYENKOVA, S. D. et al. Innovation management. Moscow: Unity, 1997. p. 9.

KOREA, Y. H. P. I. International competition. 1993.

LAZARCHIK, A. I. Assessment of the municipalities sustainable development (on the example of the Republic of Tatarstan). Science and education: current issues, achievements and innovations, p. 106, 2020.

MAKHIYANOVA, A. V.; BURGANOVA, T. A.; HUZIEVA, E. F. Trends to the social structure formation of a rural society: the ideal and real models. In: INTERNATIONAL CONGRESS ON INTERDISCIPLINARY BEHAVIOR AND SOCIAL SCIENCE, 4., 2015, Jakarta. Proceedings [...]. Jakarta, Indonesia: Kazan Federal University; ICIBSoS2015, 2015. p. 45-48.

MAKHIYANOVA, A. V.; SAYFUDINOVA, N. Z.; ROMAN, A.; TIMOFEEV, R. Methodological basis of the regional systems socio-economic profile using survey method. Journal of Economics and Economic Education Research, v. 17, n. esp. 2, p. 325-334, 2016. 
MAKHIYANOVA, A. V.; SHAKIROVA, A. F. Social portrait of the residents in the megapolis through the prism of the governmental institutions' activities. In:

INTERNATIONAL CONGRESS ON INTERDISCIPLINARY BEHAVIOR AND SOCIAL SCIENCE, 4., 2015, Jakarta. Proceedings [...]. Jakarta, Indonesia: Kazan Federal University; ICIBSoS2015, 2015. p. 141.

MAKHIYANOVA, A. V.; ZAINULLINA, M. R. Animated films for children as an agent of socialization (based on the results of content analysis). In: INTERNATIONAL CONGRESS ON INTERDISCIPLINARY BEHAVIOR AND SOCIAL SCIENCE, 4., 2015, Jakarta.

Proceedings [...]. Jakarta, Indonesia: Kazan Federal University; ICIBSoS2015, 2015. p. 41.

MAKHIYANOVA, A.; PUGACHEVA, M.; VDOVINA, S.; DEMYANOVA, O.;

LAZARCHIK, A.; GIRFANOVA, E. Regional market of medical equipment: Perspectives of development. Research Journal of Applied Sciences, v. 11, n. 11, p. 1172-1177, 2017.

REPORT "Our Common Future". Report of the international commission on environment and development. Available:

http://устойчивоеразвитие.pф/files/monographs/OurCommonFuture-introduction.pdf.

Access: 10 dec. 2020.

RUSSIA. Federal State Statistics Service. Available:

https://www.gks.ru/folder/11110/document/13282. Access: 10 dec. 2020.

RUSSIA. Message from the President of the Russian Federation to the Federal

Assembly. 2020. Available: http://kremlin.ru/events/president/news/62582. Access: 10 dec. 2020 .

\section{How to reference this article}

LAZARCHIK, A. I.; ZAINUTDINOVA, E. E.; AHMETOVA, I. A. Innovation as a factor of socio-economic development of municipal education (for example, the Republic of Tatarstan). Revista on line de Política e Gestão Educacional, Araraquara, v. 25, n. esp. 1, p. 472-481, mar. 2021. e-ISSN:1519-9029. DOI: https://doi.org/10.22633/rpge.v25iesp.1.14984

Submitted: 06/11/2020

Required revisions: 18/01/2021

Approved: $23 / 02 / 221$

Published: 01/03/2021 